\section{РОЛЬ ОБЩЕСТВЕННОГО КОНТРОЛЯ В ОБЕСПЕЧЕНИИ ДЕМОКРАТИЧЕСКИХ ВЫБОРОВ В РОССИЙСКОЙ ФЕДЕРАЦИИ}

\section{Е. В. Бердникова}

доцент кафедры конституционного и муниципального права,

Саратовский государственный университет

E-mail: berev79@yandex.ru

Введение. Статья посвящена анализу особенностей международной и конституционно-правовой регламентации общественного контроля за выборами. Цель. Основная цель работы состоит в исследовании международных и российских правовых актов, закрепляющих общественный контроль за избирательным процессом как необходимый элемент организации и проведения демократических и подлинных выборов. Результаты. Проведен анализ международной и российской нормативно-правовой базы, регламентирующей особенности организации и проведения общественного контроля в ходе избирательного процесса. Показано, что для эффективного функционирования органов публичной власти необходимо осуществление общественного контроля уже на стадии их формирования. Основным условием реализации свободных демократических выборов является использование на всех стадиях избирательного процесса общественного контрольного механизма. Заключение. Сделан вывод, что в международных правовых актах открытость и общественный контроль выступают как неотъемлемое условие проведения демократических выборов. Отечественная правовая система восприняла важнейшие условия международного правового подхода, институционализировав и применяя на практике основные формы общественного контрольного механизма на всех стадиях избирательного процесса. За последние годы в России были сделаны серьезные шаги в направлении обеспечения общественного контроля за выборами, включая создание необходимой нормативно-правовой базы. Однако представляется необходимым разработать и принять отдельный закон, закрепляющий основные принципы и формы осуществления общественного контроля за выборами в России.

Ключевые слова: общественный контроль, выборы, избирательный процесс, открытость, наблюдение.

\section{Введение}

Одной из наиболее уязвимых категорий прав человека и гражданина, подвергающихся всевозможным нарушениям при их реализации на практике, являются избирательные права и свободы граждан, позволяющие реализовать потенциал прямого народовластия. Искажение воли народа, принимавшего участие в выборах, не только нарушает его права, но и подрывает основы легитимности сформированных таким образом органов публичной власти. Поэтому важнейшим аспектом предотвращения подобных правоотношений граждан и государства служит активное задействование системы общественного контроля в избирательном процессе, который способен еще на начальной стадии выявить избирательные деликты и обеспечить прозрачное формирование легитимных властных органов.

В демократическом государстве транспарентность всех стадий избирательного процесса определяет качественный и легитимный со-

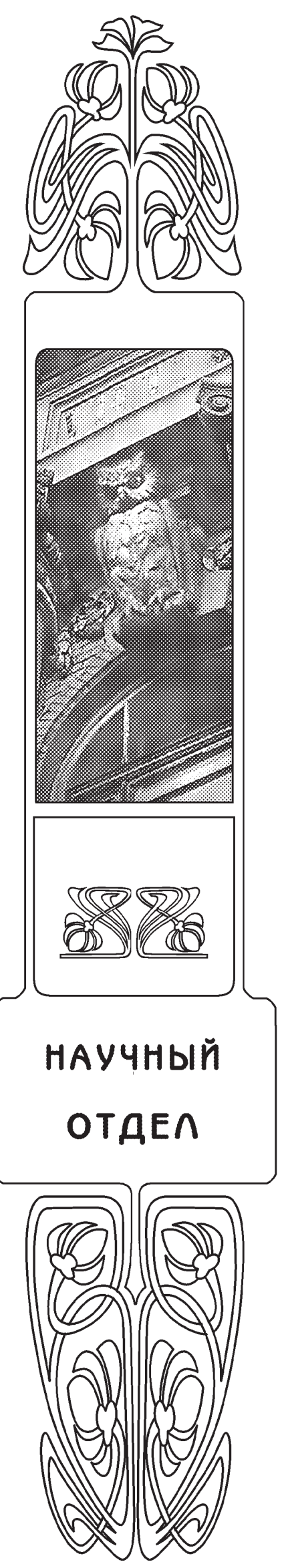


став выборных органов, и, наоборот, закрытость процедуры их формирования искажает волеизъявление граждан и минимизирует уровень доверия населения к действующей власти. Данный тезис подтверждается в Рекомендациях, способствующих участию национальных меньшинств в избирательном процессе, принятых Бюро по демократическим институтам и правам человека в Варшаве в январе 2001 г.: «Общее доверие к избирательному процессу в значительной степени зависит от всех соответствующих групп, начиная с правительства и гражданского общества, принимающих участие в формировании и деятельности избирательных органов. В этом отношении нельзя переоценить значение постоянных консультаций, общения и сотрудничества между избирательной администрацией, политическими партиями и институтами общества» [1, с. 488].

Поэтому общественному контролю должна быть подвержена не только непосредственно деятельность органов публичной власти, но и в не меньшей степени сам процесс их образования. Только этим обеспечивается непрерывность действия принципа народовластия, провозглашаемого в конституциях подавляющего числа демократических государств.

\section{Цель}

Основная цель работы состоит в исследовании международных и российских правовых актов, закрепляющих общественный контроль за избирательным процессом как необходимый элемент организации и проведения демократических и подлинных выборов.

\section{Результаты}

Контроль граждан и неправительственных организаций за подготовкой и ходом формирования публичной власти, а также определением результатов этого процесса является непосредственной гарантией осуществления подлинно демократических выборов, основанных на свободе и честности процедур на всех стадиях избирательного процесса. Открытость и общественный контроль являются взаимообусловленными элементами, так как отсутствие одного из них делает невозможной реализацию другого. Как справедливо отмечается в Постановлении Межпарламентской ассамблеи государств-участников СНГ «Об использовании международных избирательных стандартов в законодательной практике государств СНГ и Европы»: «Соблюдение принципа открытости и гласности выборов должно обеспечивать создание правовых условий для осуществления действенного общественного контроля и беспристрастного международного наблюдения за выборами» [2, с. 33].
В настоящее время в мировой практике сформировался перечень обязательных для использования в национальных правовых системах при организации избирательного процесса принципов, способствующих полноценной реализации институтов народовластия и формированию стабильной политической системы. Несмотря на то, что понятие выборов как основы организации власти в демократическом государстве стало составной частью универсальных международных норм с середины прошлого столетия - главным образом, в связи с принятием Всеобщей декларации прав человека 1948 г., открытость выборов как принцип избирательного права стал упоминаться сравнительно недавно, начиная с 90-х гг. ХХ в.

Одной из коллективных целей государствучастников ООН, провозглашенных 8 сентября 2000 г. в Декларации тысячелетия Организации Объединенных Наций, является стремление к большей открытости политических процессов, что, в свою очередь, позволяет создавать условия для подлинного участия в них всех граждан, присоединившихся к организации стран [3]. Данное положение абсолютно применимо и к выборам, которые являются составной частью политической системы общества и способствуют вовлечению граждан в управленческий процесс.

Свободные и честные выборы представляют собой ключевой элемент демократии, о чем напрямую указывается во Всеобщей декларации о демократии, принятой 16 сентября 1997 г.: «Эти выборы должны проводиться на основе всеобего, равного и тайного голосования таким образом, чтобы все избиратели могли выбрать своих представителей в условиях равенства, открытости и транспарентности, которые стимулировали бы политическую конкуренцию. Для достижения этой цели существенное значение имеют гражданские и политические права и среди них в особенности право избирать и право быть избранным, права, относящиеся к свободе выражения и собраний, доступу к информации, и право организации политических партий и осуществления политической деятельности» [4, с. 818]. Иными словами, подлинная демократия, основанная на свободном волеизъявлении граждан, невозможна без обеспечения открытой и прозрачной системы организации таких выборов.

В меморандуме, представленном группой Марокко на 98-й Межпарламентской конференции в Каире 11-16 сентября 1997 г., совершенно справедливо указано: «Выборы должны проводиться максимально честно и транспарентно. Когда имеют место мошенничество в ходе выборов, покупка голосов и искажение воли 
избирателей, те, кто избран, теряют доверие еще до того, как начнется выполнение их роли представительства» [5, с. 837]. Таким образом, в понимании мирового сообщества, транспарентность нивелирует возможность возникновения избирательных деликтов.

В региональных международно-правовых актах также акцентируется внимание на открытости выборов как неотъемлемом условии их проведения. Значительная часть этих норм заключена в документах, принятых в рамках СНГ. Так, в Конвенции СНГ о стандартах демократических выборов, избирательных прав и свобод в государствах-участниках СНГ от 7 октября 2002 г. говорится о том, что подготовка и проведение выборов должны осуществляться открыто и гласно. В ст. 7 данного документа отмечаются два основных элемента реализации механизма транспарентности выборов:

- официальное опубликование решений и правовых актов органов государственной власти, органов местного самоуправления, избирательных органов, связанных с назначением, подготовкой и проведением выборов, итогами голосования и данными об избранных лицах, обеспечением и защитой избирательных прав и свобод гражданина в порядке и сроки, предусмотренные законами;

- создание условий для осуществления общественного и международного наблюдения за выборами.

Резолюция ПАСЕ № 1897 «Демократизация выборов», принятая в 2012 г., определила три основных императива, которым должны соответствовать меры, принимаемые государствами с целью усиления демократического характера выборов: стимулирование гражданского участия, обеспечение транспарентность и усиление надзора за выборами [6].

Для преодоления проблем, наиболее часто возникающих в избирательном процессе и угрожающих легитимности проводимых выборов, Парламентская ассамблея призвала государства-члены Совета Европы осуществлять соответствующие действия, в числе которых следует особо выделить:

- обеспечение свободы политических дискуссий в СМИ, что является гарантией открытых и доступных избирательных кампаний;

- транспарентность и плюрализм всех СМИ, а также равный доступ всех кандидатов и политических партий к общественным СМИ и беспристрастность таких СМИ;

- при проведении голосования требуется правильно спланировать избирательные участки, использовать прозрачные урны, установить кабины для голосования, обеспечить публичный подсчет и правильное регулирование дистанционного голосования;

- обеспечение присутствия международных наблюдателей, в частности, в соответствии с Декларацией принципов международного наблюдения за выборами, а также Рекомендациями Венецианской комиссии в отношении международно признанного статуса наблюдателей на выборах;

- присутствие национальных наблюдателей, в том числе от гражданского общества, в соответствии с Декларацией глобальных принципов непартийного наблюдения и мониторинга выборов общественными организациями и Кодексом поведения непартийных общественных наблюдателей за выборами. При этом процедуры аккредитации должны быть простыми и легкодоступными;

- усиление надзора с целью обеспечения функционирования эффективной, транспарентной и доступной системы рассмотрения жалоб и апелляций, с тем чтобы положить конец практике безнаказанности связанных с выборами нарушений и укрепить доверие общественности к избирательному процессу.

Венецианская комиссия Совета Европы (Европейская комиссия за демократию через право) рассматривает открытость скорее не как основополагающий принцип выборов, а определяет ее в качестве условия реализации принципов демократического голосования. В данном процессе важная роль отводится наблюдению, осуществляемому на всех стадиях избирательного процесса. Выделяются три различных категории наблюдателей:

- национальные наблюдатели, являющиеся сторонниками той или иной партии или кандидата;

- национальные наблюдатели, не являющиеся сторонниками какой-либо партии или кандидата;

- международные наблюдатели, не являющиеся сторонниками какой-либо партии или кандидата.

Как отмечается в Своде рекомендуемых норм при проведении выборов, принятом Европейской комиссией за демократию через право на 52-й сессии (Венеция, 18-19 октября 2002 г.), государствам необходимо сделать процедуру наблюдения максимально широкой как на национальном, так и на международном уровне [7]. В этом случае наблюдение не должно ограничиваться непосредственно днем выборов. Контроль следует осуществлять по следующим направлениям выявления нарушений, происходящих в избирательном процессе:

- накануне выборов (например, ненадлежащее ведение списков избирателей, препятствия 
при регистрации кандидатов, случаи ограничения свободы слова и нарушения правил доступа к СМИ или государственному финансированию избирательных кампаний);

- во время выборов (например, проверка фактов давления на избирателей, множественного голосования, нарушений тайны голосования и т. д.);

- после голосования (особенно при подсчете голосов и объявлении результатов) [7].

Все вышеперечисленные стадии должны сопровождаться контролем за беспристрастностью власти, в котором определяющая роль отводится международным наблюдателям.

В Своде рекомендуемых норм при проведении выборов также указываются базовые условия деятельности международных и национальных наблюдателей при осуществлении ими контрольных функций. Они должны иметь возможность задавать вопросы любому из присутствующих, делать записи и информировать свою организацию, однако им необходимо воздерживаться от каких-либо комментариев. Кроме того, отмечается, что законодательство государств должно способствовать беспрепятственной деятельности наблюдателей, четко оговаривая места, в которых данные лица не имеют права появляться.

Отдельным пунктом Свода оговаривается, что подсчет голосов должен проводиться транспарентно. Это во многом достигается путем присутствия при подсчете голосов зарегистрированных на этом избирательном участке избирателей, национальных или международных наблюдателей, которые все без исключения могут в последующем получить копию протокола подсчета голосов. Данный тезис совпадает с мнением по данному вопросу Организации по безопасности и сотрудничеству в Европе (ОБСЕ), которая в своем Отчете «Существующие обязательства по проведению демократических выборов в государствах-участниках ОБСЕ», принятом в Варшаве 30 июня 2003 г., отметила: «Подсчет голосов и определение результатов голосования должны представлять собой прозрачный процесс, открытый для наблюдения представителями участников выборов, а также другими наблюдателями <..> Наблюдатели от международных и национальных организаций должны иметь эффективный доступ ко всем избирательным процедурам. С этой целью наблюдателям должны выдаваться соответствующие мандаты за достаточный период времени до начала выборов с тем, чтобы они могли эффективно организовать свою деятельность. Необходимое для этого законодательство должно предоставлять наблюдате- лям возможность эффективно осуществлять свою деятельность в соответствии с лучшими международными практиками по наблюдению за проведением выборов» [8, с. 521, 524].

Анализ действующего российского законодательства в сфере избирательных правоотношений позволяет прийти к выводу, что большинство международных требований, касающихся обеспечения открытости выборов и привлечения к данному процессу граждан, восприняты национальной правовой системой и отражены в базовых нормативно-правовых актах.

В качестве одного из основополагающих принципов проведения в Российской Федерации выборов и референдума Федеральным законом от 12.06.2002 № 67-Ф3 «Об основных гарантиях избирательных прав и права на участие в референдуме граждан Российской Федерации» устанавливается, что «деятельность комиссий при подготовке и проведении выборов, референдума, подсчете голосов, установлении итогов голосования, определении результатов выборов, референдума осуществляется открыто и гласно» [9]. Подсчет голосов избирателей, участников референдума осуществляется открыто и гласно с оглашением и соответствующим оформлением в увеличенной форме протокола об итогах голосования последовательно всех результатов выполняемых действий по подсчету бюллетеней и голосов избирателей, участников референдума членами участковой комиссии с правом решающего голоса.

Наблюдатели вправе присутствовать на избирательных участках с момента начала работы участковой комиссии в день голосования, а также в дни досрочного голосования и до получения сообщения о принятии вышестоящей комиссией протокола об итогах голосования, а равно при повторном подсчете голосов избирателей. Национальные наблюдатели назначаются либо зарегистрированным кандидатом, либо избирательным объединением.

Принцип независимости наблюдателей обеспечивается, в первую очередь, законодательным ограничением на назначение в их качестве выборных должностных лиц, депутатов, высших должностных лиц субъектов Российской Федерации (руководителей высших исполнительных органов государственной власти субъектов Российской Федерации), глав местных администраций, лиц, находящихся в их непосредственном подчинении, судей, прокуроров, членов комиссий с правом решающего голоса.

Наблюдателям обеспечивается доступ в помещение участковой комиссии, сформированной на избирательном участке, образованных 
в воинской части, закрытом административно-территориальном образовании, больнице, санатории, доме отдыха, местах содержания под стражей подозреваемых и обвиняемых, а также в помещение для голосования на этом избирательном участке. Они вправе присутствовать в иных комиссиях при проведении ими досрочного голосования, установлении итогов голосования, определении результатов выборов, составлении соответствующих протоколов об итогах голосования, о результатах выборов, а также при повторном подсчете голосов избирателей.

Важная роль в обеспечении открытости избирательного процесса и осуществления общественного контроля отводится представителям средств массовой информации, которые принимают участие в информационном освещении подготовки и проведения выборов. Они вправе:

а) присутствовать на заседаниях комиссий;

б) знакомиться с протоколом участковой комиссии об итогах голосования, а также с протоколами иных комиссий об итогах голосования, о результатах выборов, референдума, в том числе составляемыми повторно, получать от соответствующей комиссии копии указанных протоколов и приложенных к ним документов;

в) присутствовать на агитационных мероприятиях, освещать их проведение;

г) находиться в помещении для голосования в день голосования, в дни досрочного голосования, а также производить фото- и видеосъемку.

Более широкую регламентацию осуществления общественного контроля за подготовкой и проведением выборов определяет Федеральный закон от 26.11.1996 г. № 138-Ф3 «Об обеспечении конституционных прав граждан Российской Федерации избирать и быть избранными в органы местного самоуправления», в ст. 18 которого указано, что кандидаты, доверенные лица кандидатов, избиратели, избирательные объединения и общественные объединения имеют право на осуществление общественного контроля за подготовкой и проведением выборов [10]. Таким образом, субъектный состав, наделенный правом выдвижения национальных наблюдателей, значительно разнообразнее, нежели указанный в Федеральном законе «Об основных гарантиях избирательных прав и права на участие в референдуме граждан Российской Федерации», так как дополнен общественными объединениями и избирателями.

Деятельность наблюдателей является предметом не только законодательного регулирования, но и правоприменительной практики в виде многочисленных постановлений ЦИК, разъясняющих порядок деятельности данных лиц на выборах $[11,12]$. Помимо этого, широко распространена практика по подготовке ЦИК РФ и избирательными комиссиями субъектов РФ совместно со специалистами по избирательному праву методических рекомендаций наблюдателям за ходом избирательного процесса, в которых в доступной форме разъясняются основные аспекты их работы, полномочия, даются методические советы по осуществлению поэтапных действий наблюдателя в день голосования и при подсчете участковой избирательной комиссией голосов избирателей, составлении протокола об итогах голосования, приводятся образцы заявлений о нарушении избирательного законодательства и др. [13].

Несмотря на достаточно четкую регламентацию в российском законодательстве института наблюдения на выборах, следует констатировать, что его практическая реализация не всегда осуществляется в юридических рамках и зачастую возникают нарушения, связанные с определенными препятствиями деятельности данных лиц. Например, в Итоговом отчете Миссии по наблюдению за выборами ОБСЕ/ БДИПЧ, подготовленном по результатам выборов Президента РФ 4 марта 2012 г, указывается: «Несмотря на то, что в течение предвыборной кампании наблюдатели могли беспрепятственно выполнять свои функции, в день выборов поступали сообщения о случаях препятствования деятельности наблюдателей. Чаще всего это был отказ в доступе или удаление с участка для голосования наблюдателей от гражданского общества или от оппозиционных кандидатов. Были получены сообщения о нескольких случаях преследования наблюдателей и насилия против них. "Голос" (некоммерческая организация. $-E$. Б.) утверждала, что в течение всей избирательной кампании на организацию оказывалось постоянное давление, что на практике выражалось в частых финансовых проверках ее региональных подразделений, а также действиях досаждающего характера в отношении ее активистов» [14]. Следует отметить, что данное замечание Миссии ОБСЕ/БДИПЧ является не совсем уместным, так как российское законодательство не определяет общественные объединения в качестве субъектов наблюдения на федеральных выборах. Причем в самом Итоговом докладе отмечалось, что в процессе организации выборов этим организациям были предоставлены максимальные преференции для контроля за ходом голосования: «Президентская кампания была отмечена значительным ростом вовлеченности граждан, включая возросшее внимание к наблюдению за выборами с целью удостовериться в надлежащей организации избирательного 
процесса. Поскольку закон не предусматривает работу других местных наблюдателей кроме наблюдателей от кандидатов и политических партий, большое количество наблюдателей было направлено на участки в качестве журналистов или как представители кандидатов» [14]. В данном контексте следует говорить о том, что в последние годы весьма четко проявляется тенденция, при которой Российское государство при организации избирательного процесса на всех уровнях публичной власти способствует максимальному вовлечению представителей общественности в процедуру наблюдения на выборах.

Рост активности гражданского общества при формировании органов государственного и муниципального управления отмечается и в научной литературе. Например, Ю. А. Скокова приводит следующие данные: «...практика гражданского наблюдения на выборах во многом изменилась благодаря росту числа и активности соответствующих организаций и проектов - в 2011-2012 гг. были созданы "Гражданин наблюдатель”, “РосВыборы”, “Лига избирателей”, “Союз наблюдателей России”, корпус наблюдателей “За чистые выборы” и другие, в том числе региональные, инициативы» [15].

Анализ нормативно-правовой базы, регулирующей институт независимого наблюдения на выборах, а также практики его реализации позволяют сделать вывод о том, что правовая регламентация наблюдения за ходом избирательного процесса нуждается в определенной систематизации, выраженной в принятии отдельного федерального закона, предметом которого выступил бы общественный контроль за избирательным процессом.

Следует отметить, что в российской законодательной практике попытки принять данный нормативный правовой акт уже осуществлялись. Так, 17 апреля 1996 г. Государственной думой Федерального собрания был принят Федеральный закон «Об общественном контроле за проведением выборов и об открытости и гласности подведения итогов голосования» [16], однако в дальнейшем не прошел одобрение Совета Федерации и в конечном итоге был снят с рассмотрения [17].

В законопроекте предусматривалось участие в наблюдении за выборами, наряду с наблюдателями, представляющими кандидатов, избирательные объединения, избирательные блоки, а также доверенными лицами кандидатов, избирательных объединений, избирательных блоков, иностранными и международными наблюдателями, представителями средств массовой информации, также наблюдателей от граждан, которыми могли стать любые граждане Российской Федерации, внесенные в списки избирателей на соответствующем избирательном участке и уполномоченные не менее чем десятью другими избирателями соответствующего избирательного участка для осуществления наблюдения на данном избирательном участке.

Помимо расширенного перечня субъектов наблюдения и подробного перечня прав наблюдателей на избирательных участках, в проекте закона был отражен еще один очень важный аспект, обеспечивающий свободу, открытость и демократичность выборов, а именно право на подачу жалоб в суд в случае нарушения законодательства о выборах, причем предусматривалось, что жалобы, поданные в день выборов, должны были рассматриваться судами в этот же день и не облагаться государственной пошлиной.

Проблема судебного обжалования решений избирательных комиссий со стороны обычных граждан как избирателей, т.е. непосредственных участников избирательного процесса, являющегося одним из элементов открытости и демократичности выборов, до недавнего времени стояла достаточно остро, так как практика толкования и применения судами общей юрисдикции норм п. 1 ч. 1 ст. 134, ст. 220, ч. 1 ст. 259 ГПК РФ, а также п. 10 ст. 75 Федерального закона от 12 июня 2002 г. № 67-Ф3 «Об основных гарантиях избирательных прав и права на участие в референдуме граждан Российской Федерации» зачастую неоправданно ограничивала права данной категории субъектов. Как правило, суды при рассмотрении данной категории дел приходили к выводу о том, что в данных правоотношениях не затрагиваются права, свободы и законные интересы граждан, а затрагиваются лишь права политических партий при распределении между ними мандатов [18]. На наш взгляд, такой трактовкой суд необоснованно ограничил конституционное право гражданина на судебную защиту, отдавая приоритет интересам и правам политических партий.

22 апреля 2013 г. Конституционный суд РФ разрешил данную коллизию, указав в своем решении, что суды общей юрисдикции не вправе отказывать в принятии к рассмотрению заявлений граждан, принимавших участие в выборах в качестве избирателей, в защиту своих избирательных прав, нарушенных при установлении итогов голосования на том избирательном участке, на котором эти граждане принимали участие в выборах [19].

Современный общемировой этап государственно-правового развития демонстрирует возрастающую роль информационных технологий 
во всех сферах общественных отношений, в том числе и в сфере организации и проведения выборов. Осуществление общественного контроля за избирательным процессом в настоящее время намного упрощается, а сами выборы становятся более открытыми и прозрачными за счет того, что в избирательный процесс активно внедряются технические средства. В числе достижений электронной демократии, обеспечивающих более легкий доступ к информации об избирательном процессе, следует отнести:

1) ГАС «Выборы».

ГАС «Выборы» является федеральной автоматизированной информационной системой, функционирующей на территории Российской Федерации с 1995 г. Она применяется для автоматизации информационных процессов подготовки и проведения выборов и референдума, обеспечения деятельности избирательных комиссий, комиссий референдума, а также для решения задач, не связанных с выборами и референдумом. Как указывается в преамбуле Федерального закона от 10 января 2003 г. № 20-Ф3 «О Государственной автоматизированной системе Российской Федерации “Выборы”»: «Использование Государственной автоматизированной системы Российской Федерации “Выборы” при подготовке и проведении выборов и референдума является одной из гарантий реализации прав граждан Российской Федерации на основе обеспечения гласности, достоверности, оперативности и полноты информации о выборах и референдуме» [20];

2) электронные средства подсчета голосов и обработки информации на избирательных участках.

В своем Послании Федеральному собранию РФ от 12 ноября 2009 г. Президент РФ Д. А. Медведев отметил: «Внедрение электронных средств подсчета голосов и обработки информации на избирательных участках будет способствовать борьбе со злоупотреблениями в ходе избирательных кампаний. Следует сделать избирательную систему на региональном уровне более прозрачной» [21]. К сожалению, техническое оснащение российских избирательных участков в настоящее время еще достаточно слабое. Так, согласно данным, приведенным в Постановление ЦИК России от 22.11.2013 № 205/1378-6 «О новой редакции Программы ускоренного технического переоснащения избирательной системы Российской Федерации», по состоянию на 2007-2010 гг. в избирательной системе Российской Федерации использовалось 3150 КОИБ (3100 - КОИБ-2003 и 50 - КОИБ2010) и 5 КЭГ. Такое количество технических средств подсчета голосов обеспечило на выбо- рах Президента РФ в 2008 г. потребность всего $1,61 \%$ от общего количества избирательных участков (96614) [22];

3) средства видеонаблюдения и трансляции изображения в помещениях для голосования на выборах.

В целях обеспечения открытости и гласности в деятельности избирательных комиссий начиная с 2012 г. в российском избирательном процессе используется система видеонаблюдения и трансляции выборов. Данная система состоит из средств видеонаблюдения и трансляции изображения, устанавливаемых в помещениях для голосования, а также средств записи и хранения видеоинформации и средств обработки данных видеотрансляций, устанавливаемых в региональных центрах обработки данных Министерства связи и массовых коммуникаций Российской Федерации, для дальнейшей передачи изображения на соответствующий сайт.

Объектами видеонаблюдения являются:

- помещение для голосования в целом;

- места выдачи избирателям избирательных бюллетеней (при использовании комплексов для электронного голосования - места выдачи избирателям карточек со штрих-кодом для доступа к электронному голосованию) и работы со списком избирателей;

- стационарные и переносные ящики для голосования, а также комплексы обработки избирательных бюллетеней, переносные устройства для электронного голосования в случае их использования;

- места подсчета и погашения неиспользованных бюллетеней, подсчета бюллетеней, извлеченных из ящиков для голосования, при использовании комплексов для электронного голосования - места погашения неиспользованных карточек со штрих-кодом для доступа к электронному голосованию;

- место проведения итогового заседания участковой избирательной комиссии, увеличенная форма протокола участковой комиссии.

Следует отметить, что использование данных систем территориально ограничено, так как они не применяются при голосовании на избирательных участках, образованных в больницах и других медицинских учреждениях, имеющих стационарные отделения, местах содержания под стражей подозреваемых и обвиняемых, иных местах временного пребывания избирателей, в воинских частях (на иных избирательных участках, где голосуют военнослужащие, средства видеонаблюдения применяются по согласованию с командиром воинской части), на судах, находящихся в плавании, и на полярных станциях [23]; 
4) официальный сайт ЦИК РФ и сайты избирательных комиссий субъектов РФ.

Как указывается в Распоряжении ЦИК России от 06.03.2003 № 23-р «Об информационном обеспечении интернет-сайта и информационносправочной системы Центральной избирательной комиссии Российской Федерации»: «Основное назначение сайта Центральной избирательной комиссии Российской Федерации (www. cikrf.ru) - обеспечение большей открытости и гласности в деятельности ЦИК России, всей избирательной системы Российской Федерации, сохранение лидирующей роли ЦИК России в информировании всех участников избирательного процесса в Российской Федерации» [24]. Следует отметить, что структура и содержание интернет-портала ЦИК РФ в настоящее время позволяют не только осуществлять масштабное информирование общества о ходе выборов разного уровня, но и способствуют формированию правовой культуры российского избирателя.

\section{Заключение}

На основе изученного международного и российского опыта правового регулирования общественного контроля на выборах можно сделать следующие выводы.

1. В международных правовых актах открытость и общественный контроль выступают как неотъемлемое условие проведения демократических выборов. Данный подход также свойственен и российской правовой системе.

2. Открытость и общественный контроль должны сопровождать все стадии избирательного процесса. А потому демократические государства обязаны создавать условия, главным образом, путем четкого законодательного регулирования, для обеспечения реализации открытости и общественного контроля на всех стадиях избирательного процесса.

3. Общественный контроль на выборах реализуется в первую очередь путем обеспечения информационной открытости избирательных и иных сопровождающих данный процесс институтов и процедур, а также функционирования института наблюдателей.

4. За последние годы в России были сделаны серьезные шаги в направлении обеспечения общественного контроля за избирательным процессом, включая создание необходимой нормативно-правовой базы. Однако представляется необходимым разработать и принять отдельный закон, закрепляющий основные принципы и формы осуществления общественного контроля за выборами в России.

5. В действующем законодательстве необходимо предусмотреть возможность делегиро- вания общественных наблюдателей гражданами как основными участниками избирательного процесса на всех уровнях организации выборов.

6. В современном демократическом избирательном процессе большое значение приобретают информационные технологии, обеспечивающие значительную открытость и прозрачность процедуры голосования и облегчающие осуществление общественного контроля. Поэтому со стороны государства необходимо развивать и поощрять разнообразные формы применения электронных и технических средств в процессе организации и проведения выборов.

7. Важное значение в механизме общественного контроля за избирательным процессом играет процедура судебного обжалования решений и действий избирательных комиссий, а потому суды при рассмотрении данной категории дел должны исходить из приоритета прав и свобод граждан как основных субъектов избирательного процесса.

\section{Список литературы}

1. Рекомендации, способствующие участию национальных меньшинств в избирательном процессе. Приняты Бюро по демократическим институтам и правам человека. Варшава. Январь 2001 года // Международные избирательные стандарты. Сборник документов / отв. ред. А. А. Вешняков ; науч. ред. В. И. Лысенко. М. : Весь мир, 2004. 1152 p.

2. Об использовании международных избирательных стандартов в законодательной практике государств СНГ и Европы : постановление Межпарламентской Ассамблеи государств-участников СНГ. Принято в Санкт-Петербурге 7 декабря 2002 г. // Конвенция о стандартах демократических выборов, избирательных прав и свобод в государствах-участниках Содружества Независимых Государств : Документы и материалы / отв. ред. В. И. Лысенко. М. : РЦОИТ, 2008. $528 \mathrm{c}$.

3. Декларация тысячелетия Организации Объединенных Наций : принята 08 сентября 2000 г. Резолюцией 55/2 Генеральной Ассамблеи OOH. URL: http:// www.un.org/ru/documents/decl_conv/declarations/ summitdecl.shtml (дата обращения: 11.01.2014).

4. Всеобщая декларация о демократии : принята на 161-й сессии Межпарламентского Совета в Каире 16 сентября 1997 г. // Международные избирательные стандарты. Сборник документов / отв. ред. А. А. Вешняков ; науч. ред. В. И. Лысенко. М. : Весь мир, 2004. $1152 \mathrm{p}$.

5. Материалы 98-й Межпарламентской конференции «Обеспечение развития демократии посредством установления тесных связей между парламентом и народом» (Каир, 11-16 сентября 1997 года) // Международные избирательные стандарты. Сборник документов / отв. ред. А. А. Вешняков ; науч. ред. В. И. Лысенко. М. : Весь мир, 2004. 1152 р. 
6. Демократизация выборов : Резолюция ПАСЕ № 1897 от 03.10.2012 г. URL: http:// www.coe. int/t/r/parliamentary_assembly/[russian_documents] /\%5B2012\%5D/\%5BOct2012\%5D / Res 1897 rus.asp (дата обращения: 11.01.2014).

7. Свод рекомендуемых норм при проведении выборов. Руководящие принципы и пояснительный доклад. URL: http://www.cikrf.ru/international/docs/ parlam_ass_rus.html (дата обращения: 11.01.2014).

8. Отчет «Существующие обязательства по проведению демократических выборов в государствах-участниках ОБСЕ». Принят Организацией по безопасности и сотрудничеству в Европе. Варшава. 30 июня 2003 года // Международные избирательные стандарты. Сборник документов / отв. ред. А. А. Вешняков ; науч. ред. В. И. Лысенко. М. : Весь мир, 2004. 1152 р.

9. Об основных гарантиях избирательных прав и права на участие в референдуме граждан Российской Федерации : федер. закон от 12.06.2002 № 67-Ф3 (ред. от 21.02.2014) // Собр. законодательства Рос. Федерации. 2002. № 24, ст. 2253 ; 2014. № 8, ст. 739.

10. Об обеспечении конституционных прав граждан Российской Федерации избирать и быть избранными в органы местного самоуправления : федер. закон от 26.11.1996 № 138-Ф3 (ред. от 28.12.2013) // Собр. законодательства Рос. Федерации. 1996. № 49, ст. 5497 ; 2013. № 52 (ч. І), ст. 6961.

11. О Разъяснении порядка ведения наблюдателями фотои (или) видеосъемки в помещении для голосования : постановление ЦИК России от 03.10.2012 № 143/1085-6 // Вестн. ЦИК России. 2012. № 10. С. 144-146.

12. О Разъяснениях порядка деятельности иностранных (международных) наблюдателей при проведении выборов Президента Российской Федерации и об удостоверении иностранного (международного) наблюдателя : постановление ЦИК России от 12.05.2011 № 10/98-6 // Вестн. ЦИК России. 2011. № 7. С. 63-72.

13. Памятка наблюдателя на выборах Президента Российской Федерации 4 марта 2012 года / Центральная избирательная комиссия Российской Федерации. М. : РЦОИТ, 2012. 48 c.

14. Итоговый отчет Миссии по наблюдению за выборами ОБСЕ/БДИПЧ, подготовленный по результатам выборов Президента РФ 4 марта 2012 года. Варшава. 11 марта 2012 года. URL: http://www.osce.org/ru/odihr/ elections/90462 (дата обращения: 11.01.2014).

15. Скокова Ю. А. Трансформация практики гражданского наблюдения на выборах в России // Гражданское общество в России и за рубежом. 2013. № 2. Доступ из справ.-правовой системы «КонсультантПлюс».

16. О Федеральном законе «Об общественном контроле за проведением выборов и об открытости и гласности подведения итогов голосования» : постановление ГД ФС РФ от 17.04.1996 № 251-ІІ ГД // Собр законодательства Рос. Федерации. 1996. № 17, ст. 1920.

17. Об общественном контроле за проведением выборов и об открытости и гласности подведения итогов голосования : проект Федерального закона № 96700363-2. Документ опубликован не был. Доступ из справ.правовой системы «КонсультантПлюс».
18. Пояснение по существу жалобы Белова О. Б. на нарушение его конституционных прав пунктом 1 части 1 статьи 134, статьей 220, частью 1 статьи 259 ГПК РФ, а также пунктом 10 ст. 75 Федерального закона от 12.06.2002 № 67-Ф3 «Об основных гарантиях избирательных прав и права на участие в референдуме граждан Российской Федерации». URL: http:// sutyajnik.ru/documents/4447.html (дата обращения: 11.01.2014).

19. По делу о проверке конституционности статей 3 , 4, пункта 1 части первой статьи 134, статьи 220 , части первой статьи 259, части второй статьи 333 Гражданского процессуального кодекса Российской Федерации, подпункта «з» пункта 9 статьи 30, пункта 10 статьи 75, пунктов 2 и 3 статьи 77 Федерального закона «Об основных гарантиях избирательных прав и права на участие в референдуме граждан Российской Федерации», частей 4 и 5 статьи 92 Федерального закона «О выборах депутатов Государственной Думы Федерального Собрания Российской Федерации» в связи с жалобами граждан А.В. Андронова, О. О. Андроновой, О. Б. Белова и других, Уполномоченного по правам человека в Российской Федерации и регионального отделения политической партии СПРАВЕДЛИВАЯ РОССИЯ в Воронежской области : постановление Конституционного Суда РФ от 22.04.2013 № 8-П // Собр законодательства Рос. Федерации. 2013. № 18, ст. 2292.

20. О Государственной автоматизированной системе Российской Федерации «Выборы» : федер. закон от 10.01.2003 № 20-Ф3 (ред. от 28.12.2013) // Собр законодательства Рос. Федерации. 2003. № 2, ст. 172 ; 2013. № 52 (ч. І), ст. 6961.

21. Послание Президента РФ Дмитрия Медведева Федеральному Собранию Российской Федерации от 12.11.2009 г. // Рос. газ. 2009. 13 нояб.

22. О новой редакции Программы ускоренного технического переоснащения избирательной системы Российской Федерации : постановление ЦИК России от 22.11.2013 № 205/1378-6. Документ опубликован не был. Доступ из справ.-правовой системы «КонсультантПлюс».

23. О Порядке применения средств видеонаблюдения и трансляции изображения в помещениях для голосования на выборах и референдумах, проводимых в Российской Федерации : постановление ЦИК России от 26.09.2012 № 142/1076-6 // Вестн. ЦИК России. 2012. № 10. С. $118-134$.

24. Об информационном обеспечении интернет-сайта и информационно-справочной системы Центральной избирательной комиссии Российской Федерации (вместе с «Регламентом подготовки и размещения информационных ресурсов на интернет-сайте и в информационно-справочной системе Центральной избирательной комиссии Российской Федерации», «Временным порядком приема и обработки сообщений, поступающих в ЦИК России по электронной почте сети Интернет») : распоряжение ЦИК России от 06.03.2003 № 23-p. Документ опубликован не был. Доступ из справ.-правовой системы «КонсультантПлюс». 


\title{
The Role of Public Control to Ensure Democratic Elections in the Russian Federation
}

\author{
E. V. Berdnikova \\ Saratov State University, \\ 83, Astrakhanskaya str., Saratov, 410012, Russia \\ E-mail: berev79@yandex.ru
}

Introduction. The article analyzes the features of international and constitutional legal regulation of public control over elections. Object. The main object of this paper is to study Russian and international legal acts that perpetuate public control over the electoral process as a necessary element of the organization and conduction of democratic elections and genuine. Results. The author analyzes the Russian and international legal framework regulating features of the organization and conduction of public control in the electoral process. It is shown that the effective functioning of the public authorities need to exercise social control at the time of their formation. The main condition for the realization of free and democratic elections is to use at all stages of the electoral process, a control mechanism. Conclusion. The author concludes that in international legal acts openness and public control act as an essential condition for democratic elections. Domestic legal system accepted the conditions of the most important international legal approach, institutionalized and putting into practice the basic forms of social control mechanism at all stages of the electoral process. In recent years, Russia had made serious steps to ensure public control over elections, including the establishment of the necessary legal framework. However, it is necessary to develop and adopt a separate law that secures the basic principles and forms of public oversight of elections in Russia.

Key words: social control, elections, electoral process, openness, observation.

\section{References}

1. Rekomendacii, sposobstvujushhie uchastiju nacional'nyh men'shinstv v izbiratel'nom processe. Prinjaty Bjuro po demokraticheskim institutam i pravam cheloveka. Varshava. Janvar' 2001 goda [Guidelines to Assist National Minority Participation in the electoral process. Adopted by the Office for Democratic Institutions and Human Rights. Warsaw. January 2001. Mezhdunarodnye izbiratel'nye standarty. Sbornik dokumentov [International electoral standards. Collection of documents]. Moscow, The whole world, 2004. 1152 p.

2. Ob ispol'zovanii mezhdunarodnyh izbiratel'nyh standartov v zakonodatel'noj praktike gosudarstv SNG i Evropy: postanovlenie Mezhparlamentskoj Assamblei gosudarstv-uchastnikov SNG. Prinjato v Sankt-Peterburge 7 dekabrja 2002 goda [On the use of international electoral standards in the legislative practice of the CIS and Europe. Resolution of the Interparliamentary Assembly of the CIS member-states. Adopted in St. Petersburg, December 7, 2002]. Konvencija o standartah demokraticheskih vyborov, izbiratel'nyh prav i svobod $v$ gosudarstvah-uchastnikah Sodruzhestva Nezavisimyh Gosudarstv: Dokumenty i materialy. Otv. red. V. I. Lysenko [Convention on the Standards of Democratic Elections, Electoral Rights and Freedoms in the Member States of the Commonwealth of Independent States. Documents and Materials. Ed. V. I. Lysenko]. Moscow, RCOIT, 2008. 528 p.

3. Deklaracija tysjacheletija Organizacii Ob\#edinennyh nacij. Prinjata 08 sentjabrja 2000 g. Rezoljuciej 55/2 General'noj Assamblei OON (Millennium Declaration of the United Nations. Adopted September 8, 2000 Resolution 55/2 United Nations General Assembly). Available at: http://www.un.org/ru/documents/decl_conv/ declarations/ summitdecl.shtml (accessed 11 January 2014).

4. Vseobshhaja deklaracija o demokratii: Prinjata na 161-j sessii Mezhparlamentskogo Soveta v Kaire 16 sentjabrja 1997 goda [The Universal Declaration on Democracy:
Adopted at the 161st session of the Inter-Parliamentary Council in Cairo on September 16, 1997]. Mezhdunarodnye izbiratel'nye standarty. Sbornik dokumentov [International electoral standards. Collection of documents]. Moscow, The whole world, 2004. 1152 p.

5. Materialy 98-j Mezhparlamentskoj konferencii «Obespechenie razvitija demokratii posredstvom ustanovlenija tesnyh svjazej mezhdu parlamentom i narodom» (Kair, 11-16 sentjabrja 1997 goda) [Proceedings of the 98th Inter-Parliamentary Conference «Ensuring the development of democracy through the establishment of closer ties between the parliament and the people» (Cairo, 11-16 September 1997)]. Mezhdunarodnye izbiratel'nye standarty. Sbornik dokumentov [International electoral standards. Collection of documents]. Moscow, The whole world, 2004. 1152 p.

6. Demokratizacija vyborov. Rezoljucija PASE №1897 ot 03.10.2012 g. (Democratization of the election. PACE resolution number 1897 of 03.10 .2012 ). Available at: http:// www.coe.int/t/r/parliamentary_assembly/ [russian_documents] $/ \% 5 \mathrm{~B} 2012 \% 5 \mathrm{D} / \% 5 \mathrm{BOct} 2012 \% 5 \mathrm{D}$ / Res1897_ rus.asp (accessed 11 January 2014).

7. Svod rekomenduemyh norm pri provedenii vyborov. Rukovodjashhie principy i pojasnitel'nyj doklad (Code of Good Practice in Electoral Matters . Guidelines and explanatory report). Available at: http://www.cikrf.ru/ international/docs/parlam_ass_rus.html (accessed 11 January 2014).

8. Otchet «Sushhestvujushhie objazatel'stva po provedeniju demokraticheskih vyborov v gosudarstvah-uchastnikah OBSE». Prinjat Organizaciej po bezopasnosti i sotrudnichestvu v Evrope. Varshava. 30 ijunja 2003 goda [Report «Existing Commitments for Democratic Elections in the states-participants of the OSCE». Adopted by the Organization for Security and Cooperation in Europe. Warsaw, June 30, 2003]. Mezhdunarodnye izbiratel'nye standarty. Sbornik dokumentov [International electoral standards. Collection of documents]. Moscow, The whole world, 2004. 1152 p.

9. Ob osnovnyh garantijah izbiratel'nyh prav i prava na 
uchastie v referendume grazhdan Rossijskoj Federacii: federal'nyj zakon ot 12.06.2002 № 67-FZ (red. ot 21.02.2014) [On basic guarantees of electoral rights and the right to participate in the referendum of the citizens of the Russian Federation. Federal Law of 12.06.2002 № 67-FZ (as amended on 21.02.2014)]. Sobranie zakonodatel'stva $R F$ [Collection of laws of the Russian Federation], 2002, no. 24, art. 2253; 2014, no. 8 , art. 739 .

10. Ob obespechenii konstitucionnyh prav grazhdan Rossijskoj Federacii izbirat' i byt' izbrannymi v organy mestnogo samoupravlenija: federal'nyj zakon ot 26.11.1996 № 138-FZ (red. ot 28.12.2013) [On ensuring the constitutional rights of citizens of the Russian Federation to elect and be elected to bodies of local self-government: the federal law from 26.11.1996 № 138-FZ (as amended on 28.12.2013). Sobranie zakonodatel'stva RF [Collection of laws of the Russian Federation], 1996, no. 49, art. 5497; 2013, no. 52 (pt. I), art. 6961.

11. O Raz\#jasnenii porjadka vedenija nabljudateljami fotoi (ili) videos\#emki v pomeshhenii dlja golosovanija: postanovlenie CIK Rossii ot 03.10.2012 № 143/1085-6 [For clarification of the order of reference observers photo and (or) video at the polling station. Russian CEC decision from 03.10.2012 № 143/1085-6]. Vestnik Tsentral 'noi izbiratel'noi komissii Rossiiskoi Federatsii [Bulletin of the Central Election Commission of the Russian Federation], 2012, no.10, pp. 144-146.

12. O Raz\#jasnenijah porjadka dejatel'nosti inostrannyh (mezhdunarodnyh) nabljudatelej pri provedenii vyborov Prezidenta Rossijskoj Federacii i ob udostoverenii inostrannogo (mezhdunarodnogo) nabljudatelja: postanovlenie CIK Rossii ot 12.05.2011 № 10/98-6 [For clarification about the activities of foreign (international) observers at the elections of the President of the Russian Federation and to the identity of the foreign (international) observer. Russian CEC decision from 12.05.2011 № 10/98-6]. Vestnik Tsentral'noi izbiratel'noi komissii Rossiiskoi Federatsii [Bulletin of the Central Election Commission of the Russian Federation], 2011, no. 7, pp. 63-72.

13. Pamjatka nabljudatelja na vyborah Prezidenta Rossijskoj Federacii 4 marta 2012 goda [Memo election observer Russian President March 4, 2012]. Moscow, RCOIT, 2012. $48 \mathrm{~s}$.

14. Itogovyj otchet Missii po nabljudeniju za vyborami OBSE/BDIPCh, podgotovlennyj po rezul'tatam vyborov Prezidenta RF 4 marta 2012 goda. Varshava. 11 marta 2012 goda (Final Report of the Observer Mission in OSCE/ODIHR Election, following the results of presidential elections March 4, 2012. Warsaw. March 11, 2012). Available at: http://www.osce.org/ru/odihr/ elections/90462 (accessed 11 January 2014).

15. Skokova Yu. A. Transformacija praktiki grazhdanskogo nabljudenija na vyborah v Rossii (Transformation Practice for Civil observations on elections in Russia). Grazhdanskoe obshhestvo v Rossii i za rubezhom (Civil Society in Russia and abroad), 2013, no. 2. ATP «Consultant» [electronic resource].
16. O Federal'nom zakone «Ob obshhestvennom kontrole za provedeniem vyborov i ob otkrytosti i glasnosti podvedenija itogov golosovanija». Postanovlenie GD FS RF ot 17.04.1996 № 251-II GD [About the Federal Law «On public control over elections, and on the openness and transparency of voting results». Decision the State Duma from 17.04.1996 № 251-II GD]. Sobranie zakonodatel'stva RF [Collection of laws of the Russian Federation], 1996, no. 17, art. 1920.

17. Ob obshhestvennom kontrole za provedeniem vyborov i ob otkrytosti i glasnosti podvedenija itogov golosovanija: proekt Federal'nogo zakona № 96700363-2. Dokument opublikovan ne byl (Dostup iz SPS «Konsul'tantPljus 11.01.2014) [On public control over elections, and on the openness and transparency of voting results. Draft Federal law № 96700363-2. The document has not been published. ATP «Consultant» [electronic resource].

18. Pojasnenie po sushhestvu zhaloby Belova O.B. na narushenie ego konstitucionnyh prav punktom 1 chasti 1 stat'i 134, stat'ej 220, chast'ju 1 stat'i 259 GPK RF, a takzhe punktom 10 st. 75 Federal'nogo zakona ot 12.06.2002 № 67-FZ «Ob osnovnyh garantijah izbiratel'nyh prav i prava na uchastie $\mathrm{v}$ referendume grazhdan Rossijskoj Federacii» (The Explanation on the merits $\mathrm{O}$. B. Belova a violation of his constitutional rights, paragraph 1 of Part 1 of Article 134, Article 220, Paragraph 1 of Article 259 of the Code of Civil Procedure of the Russian Federation, as well as paragraph 10 of Art. 75 of the Federal law of 12.06.2002 № 67-FZ «On Basic Guarantees of Electoral Rights and the right to participate in a referendum of citizens of the Russian Federation»). Available at: http://sutyajnik. ru/documents/4447.html (accessed 11 January 2014).

19. Po delu o proverke konstitucionnosti statej 3, 4, punkta 1 chasti pervoj stat'i 134 , stat'i 220 , chasti pervoj stat'i 259, chasti vtoroj stat'i 333 Grazhdanskogo processual'nogo kodeksa Rossijskoj Federacii, podpunkta «Z» punkta 9 stat'i 30 , punkta 10 stat'i 75 , punktov 2 i 3 stat'i 77 Federal'nogo zakona «Ob osnovnyh garantijah izbiratel'nyh prav i prava na uchastie v referendume grazhdan Rossijskoj Federacii», chastej 4 i 5 stat'i 92 Federal'nogo zakona «O vyborah deputatov Gosudarstvennoj Dumy Federal'nogo Sobranija Rossijskoj Federacii» v svjazi s zhalobami grazhdan A. V. Andronova, O. O. Andronovoj, O. B. Belova i drugih, Upolnomochennogo po pravam cheloveka v Rossijskoj Federacii i regional'nogo otdelenija politicheskoj partii SPRAVEDLIVAJa ROSSIJa v Voronezhskoj oblasti: postanovlenie Konstitucionnogo Suda RF ot 22.04.2013 № 8-P [On verification of constitutionality of Articles 3, 4, paragraph 1, of the first part of Article 134, Article 220, Article 259 of the first part, the second part of Article 333 of the Civil Procedure Code of the Russian Federation, paragraph «h» of paragraph 9 of Article 30, paragraph 10 of Article 75, paragraphs 2 and 3 of Article 77 of the Federal law «On basic Guarantees of electoral Rights and the right to Participate in referendum in the Russian Federation», parts 4 and 5 of Article 92 of the Federal law «On the Election of 
Deputies of the State Duma of the Federal Assembly of the Russian Federation» in response to complaints from citizens A. V. Andronov, O. O. Andronova, O. B. Belov and others, the Commissioner for Human Rights in the Russian Federation and the regional branch of the political party JUST RUSSIA in Voronezh Region. Decision of the Constitutional Court of the Russian Federation of 22.04.2013 № 8-P. Sobranie zakonodatel'stva RF [Collection of laws of the Russian Federation], 2013, no. 18 , art. 2292.

20. O Gosudarstvennoj avtomatizirovannoj sisteme Rossijskoj Federacii «Vybory»: federal'nyj zakon ot 10.01.2003 № 20-FZ (red. ot 28.12.2013) [On the State Automated System of the Russian Federation «Elections». Federal law from 10.01.2003 № 20-FZ (as amended on 28.12.2013)]. Sobranie zakonodatel'stva $R F$ [Collection of laws of the Russian Federation], 2003, no. 2, art. 172; 2013, no. 52 (pt. I), art. 6961.

21. Poslanie Prezidenta RF Dmitrija Medvedeva Federal'nomu Sobraniju Rossijskoj Federacii ot 12.11.2009 g. [Message of President Dmitry Medvedev to the Federal Assembly of the Russian Federation dated 12.11.2009]. Rossiiskaja gazeta [Russian newspaper], 2009, 13 November.

22. O novoj redakcii Programmy uskorennogo tehnicheskogo pereosnashhenija izbiratel'noj sistemy Rossijskoj Federacii: postanovlenie CIK Rossii ot 22.11.2013 № 205/1378-6 (On the new edition of the Quick technical modernization of the electoral system of the Russian Federation. Russian CEC decision from 22.11.2013 № 205/1378-6). The document has not been published. ATP «Consultant» [electronic resource].
23. O Porjadke primenenija sredstv videonabljudenija i transljacii izobrazhenija $\mathrm{v}$ pomeshhenijah dlja golosovanija na vyborah i referendumah, provodimyh v Rossijskoj Federacii: postanovlenie CIK Rossii ot 26.09.2012 № 142/1076-6 [On the application of video surveillance and broadcast images of the premises for voting in elections and referendums held in the Russian Federation. Russian CEC decision from 26.09.2012 № 142/1076-6. Vestnik Tsentral'noi izbiratel'noi komissii Rossiiskoi Federatsii [Bulletin of the Central Election Commission of the Russian Federation], 2012, no. 10 , pp. $118-134$.

24. Ob informacionnom obespechenii internet-sajta i informacionno-spravochnoj sistemy Central'noj izbiratel'noj komissii Rossijskoj Federacii (vmeste s «Reglamentom podgotovki i razmeshhenija informacionnyh resursov na internet-sajte $\mathrm{i} v$ informacionno-spravochnoj sisteme Central'noj izbiratel'noj komissii Rossijskoj Federacii», «Vremennym porjadkom priema i obrabotki soobshhenij, postupajushhih v CIK Rossii po jelektronnoj pochte seti Internet»): rasporjazhenie CIK Rossii ot 06.03.2003 № 23-r (Providing information about the website and informational system of the Central Election Commission of the Russian Federation (with the «Regulations of the preparation and placement of information resources on the website and in the reference system of the Central Election Commission of the Russian Federation», "Time of the order and message processing entering the Russian Central Election Commission by e-mail on the Internet»). Order Russian CEC from 06.03.2003 № 23-r). The document has not been published. ATP «Consultant» [electronic resource]. 